\title{
Utilization of Customs Regulations Related to Import Export Insurance in Supporting the Export Process
}

\author{
Ardiansyah \\ Program Studi Ilmu Hukum, STIH IBLAM \\ Email: ardiansyah@iblam.ac.id
}

\begin{abstract}
The impact of the ongoing COVID-19 pandemic requires a precise strategy to encourage export activities. This community service activity aims to provide education for practitioners and academics in the insurance sector in understanding more deeply the use of customs regulations related to import export insurance in order to strengthen the important role of trade insurance and marine cargo in supporting the export process. There are various customs regulations that can be used by businesses related to insurance, namely: First, the use of domestic insurance will reduce the payment of import duties and taxes for imports because they are not included in the import value. Second, the use of guarantees from insurance companies (customs bonds) as a solution for paying state levies for companies that are unable to pay off these levies immediately and in utilizing customs facilities aimed at boosting national export performance. Among the customs facilities that can be utilized are bonded zone and Import Facility for Export Purpose (KITE). Both facilities are intended to provide fiscal and procedural facilities to producer exporters. The use of customs facilities requires guarantees for import duties and import taxes. One type of guarantee is a guarantee from an insurance company (customs bond). Based on this activity, participants can take advantage of customs regulations related to import-export insurance which ultimately aims to encourage export activities, especially during this pandemic.
\end{abstract}

Keywords: Customs Regulation, Insurance, Export.

\section{A. INTRODUCTION}

Economic conditions have deteriorated considerably due to the impact of the ongoing COVID-19 pandemic. Many aspects of life are affected by unstable economic conditions, including the business environment. In addition, the community is also affected from the social and psychological side, where there is still a sense of fear of the dangers of COVID-19 and high uncertainty in the future (Safari, 2020; Sinaga \& Rivani, 2020). The government is still trying to suppress the impacts caused by the COVID-19 pandemic through various policies. Economic conditions and policy responses from business players require a precise strategy to encourage the economy, one of which is to encourage export activities in international trade.

In international trade activities, insurance documents play an important role because this document will protect the exporter or importer against loss, damage or loss that takes place throughout the process of exporting goods (Soebandiyo et al.,2012). Based on article 246 of the KUHD, insurance is concluded as an agreement that explains that the insurer (insurer) promises to compensate for losses related to damage and losses faced by the insured (insured) or caused by unexpected events.

In a sales contract between an exporter and an importer, it is generally stated that the price offered has included insurance costs or not. For example, in a contract in the form of 
FOB or CIF, an importer is responsible for goods insurance, while in a CIF contract the insurance coverage is carried out by the exporter. For export and import transactions, insurance in the transportation of goods by sea is known as marine insurance (Firmansyah \& Arham, 2021).

This community service activity aims to provide education for practitioners and academics in the insurance sector in understanding more deeply the use of customs regulations related to import export insurance in order to strengthen the important role of trade insurance and marine cargo in supporting the export process (Zakariya, 2020; Djunaedi et al.,2019). There are various customs regulations that can be used by businesses related to insurance, namely: First, the use of domestic insurance will reduce the payment of import duties and taxes for imports because they are not included in the import value. Second, the use of guarantees from insurance companies (customs bonds) as a solution for paying state levies for companies that are unable to pay off these levies immediately and in utilizing customs facilities aimed at boosting national export performance (Syaifulloh \& Ramdany, 2020; Afandi, 2011). Among the customs facilities that can be utilized are bonded zone facilities and facilities for Imports for Export Purposes (KITE). Both facilities are intended to provide fiscal and procedural facilities to producer exporters whose use requires guarantees, one of which is a guarantee from an insurance company (customs bond). Based on this activity, participants can take advantage of customs regulations related to insurance which ultimately aim to encourage export activities, especially during this pandemic.

\section{B. METHOD}

This community service activity is carried out in the form of a web seminar (webinar) through video conference applications and live broadcasts. The method of implementing this activity consists of two steps (Kartika, 2016).

The first step is planning. This step is very important so that the team and the organizers can identify problems, outputs, and the desired activity targets so that the results of these activities can meet the expectations of various parties. In addition, the team also held internal discussions regarding the preparation of materials to be delivered in this community service activity webinar to ensure the suitability of the material with the topics reviewed. The parties involved are practitioners and academics in the insurance sector in understanding more deeply the use of customs regulations related to export-import insurance in order to strengthen the important role of trade insurance and marine cargo in supporting the export process. For this reason, the parties involved in this activity are (Figure 1):

1. PT. SMS Consultans (sebagai penyelenggara),

2. PT. Asuransi Ekspor Indonesia (Persero),

3. PT. Tugu Reasuransi Indonesia (Perseroan/Tugure),

4. PT. Axis International Indonesia,

5. PT. Prima Adjusterindo Mandiri / Prima Adjusters

6. STIE Bisnis-Indonesia

7. PT Matthews Daniel International

8. IZN Advocates 


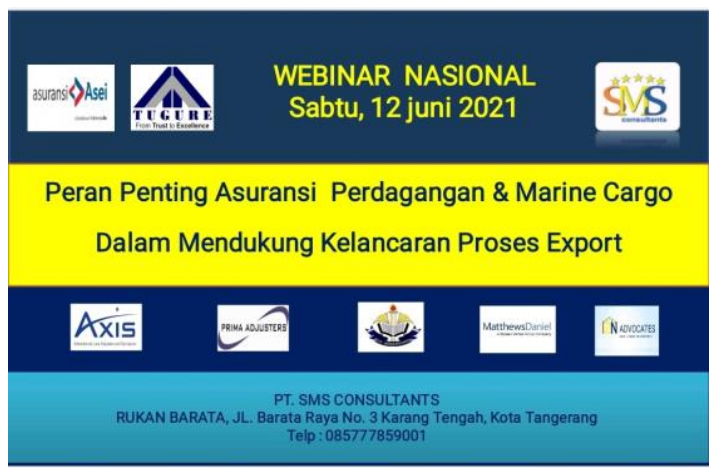

Figure1. Activity Flyer

Next, the second step in this activity is the implementation of the activity. This activity was carried out in the form of a talk show in the form of material delivery and discussions conducted by Team members as resource persons and moderators (Figure 2). The resource persons are practitioners and academics who master international insurance and customs law, so that they are relevant to the delivery of the material. The materials presented related to the use of customs regulations related to import export insurance in strengthening the important role of trade insurance and marine cargo in supporting the export process (Deyanputri, 2020; Fatimah et al.,2016). The activity was carried out in the form of interactive discussions so that participants could directly ask questions to the team members who served as resource persons and moderators.

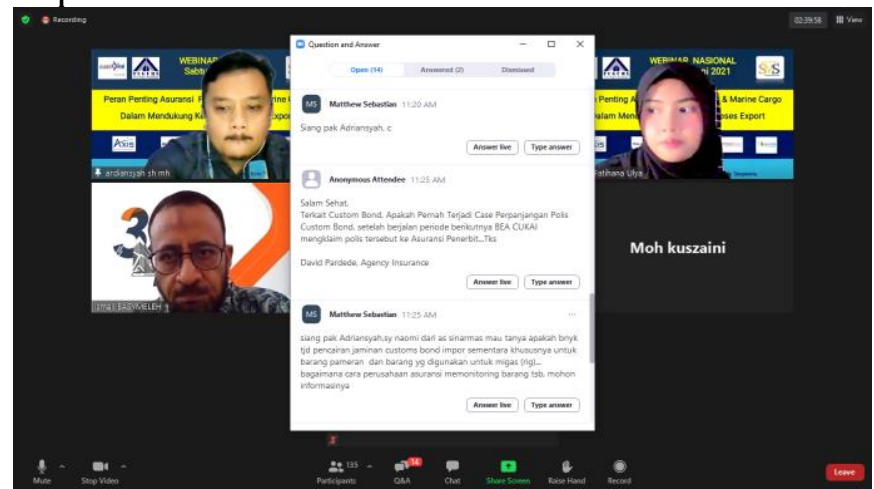

Figure 2. Presentation of Material and Questions and Answers

\section{RESULT AND DISCUSSION}

The webinar with the theme of the Importance of Import Export Insurance in Supporting the Export Process was held at PT. SMS Consultants (as the organizer) in collaboration with PT. Indonesian Export Insurance (Persero), on June 12, 2021 at 09.00 11.00 WIB using Zoom conference. Those participating in this activity are exporters, cargo owners, transporters, MSMEs, students and the general public (Figure 4). The participants are spread across various regions in Indonesia.

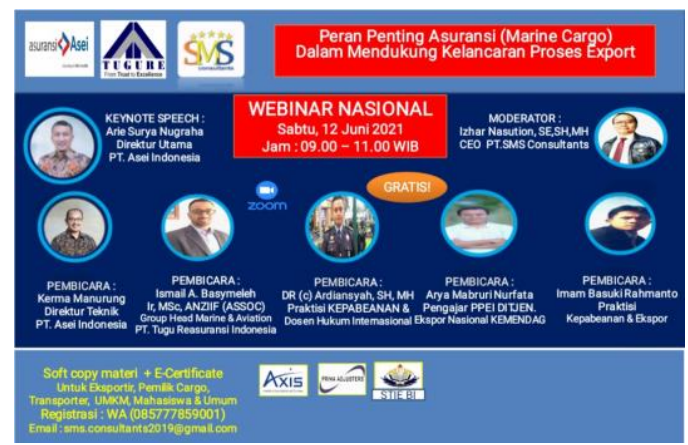

Figure 3. Details of Activities 
At the implementation stage of the activity, the resource person delivered material on customs regulations related to import-export insurance. This activity has a talk show concept which is divided into two sessions. In the first session of material delivery. the matters submitted related to customs regulations on export-import insurance, namely as follows:

\section{Insurance as part of Customs Value in CIF incoterm}

Customs value regulation is sourced from international law/agreement, in this case the Agreement on Implementation of Article VII of General Agreement on Trade and Tariff (GATT) 1994 WTO Valuation Agreement and its Valuation Compendium. Article 8 Pharagraph (2) of the WTO Valuation Agreement stipulates that each member country must include provisions on fees that are exempt or mandatory from customs value, namely: (a) transportation of imported goods to the port or place of import; (b) loading, unloading and handling related to the transportation of imported goods to the port or place of import; and (c) insurance.

Article 8 paragraph (2) provides options for contracting parties to include or not include, in whole or in part, the components of transportation costs, loading costs, unloading costs, and handling costs related to the transportation of imported goods to port or place of import and insurance costs. Therefore the contracting parties can choose whether or not the CIF component should be included in the calculation of their customs value. In this regard, ASEAN countries have agreed to include the CIF component in the calculation of their customs value (Bahagiawati \& Sutrisno, 2007).

Indonesia further regulates the imposition of insurance and additional costs in customs value, namely in the Regulation of the Minister of Finance Number 160/PMK.04/2010 concerning Customs Value for Calculation of Import Duty as last amended by Regulation of the Minister of Finance Number 62/PMK.04/2018, mentioned in Article 2 paragraphs (1) and (2) as follows: (1) Customs value for calculating import duty is the transaction value of the import goods concerned that meet certain conditions. (2) The customs value as referred to in paragraph (1) is the customs value in the International Commercial Terms (incoterms) Cost, Insurance and Freight (CIF).

\section{Conditions for Adding Insurance Fees to Transaction Value}

a. Insurance Document Dated before or no later than the delivery date

Based on Attachment I Number 4 to the Regulation of the Minister of Finance Number 160/PMK.04/2010 concerning Customs Value for Calculation of Import Duty as last amended by Regulation of the Minister of Finance Number 62/PMK.04/2018, it is explained related to fees added to the actual price paid or that should be paid, one of which is the cost of insurance as evidenced by insurance documents dated before or no later than the date of delivery, as follows:

"Insurance costs are the costs of guaranteeing the transportation of goods from overseas export places to import places in the Customs Area which are generally proven by insurance documents in the form of insurance certificates, insurance policies or open policies. The date of the insurance document must be before or no later than the date of delivery;

In the event that the insurance costs as referred to in Article 5 paragraph (3) letter g, are not included in the transaction value and tangible evidence or objective and measurable data regarding the amount of insurance costs are not available, the amount of insurance costs used in determining the customs value as referred to in Article 21 of this Regulation of the Minister of Finance; 
b. Insurance value has not been added to the transaction price

Based on the Attachment to the Regulation of the Minister of Finance number 34/PMK.04/2016 concerning amendments to the Regulation of the Minister of Finance number 160/PMK.04/2010 concerning Customs Value for Calculation of Import Duty, there are provisions for additional conditions to the price actually paid or should be paid.

The customs value for calculating import duties is based on the delivery price of Cost Insurance and Freight, where the elements of transportation costs, packing costs (loading), unloading costs, and handling costs related to the transportation of imported goods to the port or place of import and insurance costs must be paid. added to the price actually paid or payable, unless it is done after the import (Ashar, 2019). Treat the buyer's notification of the value of the goods in accordance with the delivery terminology, including the following:

Ex Works. The importer must submit to the customs authorities: (1) the value of the goods based on the delivery of the Ex Works; (2) the amount of the fee is accompanied by proof of payment of transportation costs, loading costs, unloading costs, and handling costs related to the transportation of imported goods to the port or place of import and insurance costs. Proof of payment must be issued by the competent authority.

Free On Board (FOB). Importers must submit to customs authorities: (1) Value of goods based on FOB delivery; (2) The amount of the fee is accompanied by proof of payment of transportation costs, loading costs, unloading costs, and handling costs related to the transportation of imported goods to the port or place of import and insurance costs. Proof of payment must be issued by the competent authority.

Cost and Freight (CFR) atau Cost Insurance and Freight (CIF). The importer must submit to the customs authorities: (1) the value of the goods based on the delivery of CFR or CIF; (2) the amount of insurance cost is accompanied by proof of insurance payment. Proof of payment must be issued by the competent authority.

Delivered Duty Paid (DDP). The importer must submit to the customs authorities: (1) the value of the goods based on the DDP submission; (2) the amount of costs incurred after importation. Proof of payment must be issued by the competent authority.

c. Free Of Charge (FOC) conditions or not supported by evidence

It is stated in Number 5 letter c Attachment to the Regulation of the Minister of Finance number 34/PMK.04/2016 concerning amendments to the Regulation of the Minister of Finance number 160/PMK.04/2010 concerning Customs Value for Calculation of Import Duty:

"In terms of transportation costs, loading, unloading and handling costs as well as insurance costs: 1) None (free of charge); 2) Not supported by real evidence or objective and measurable data, then the customs value cannot be determined based on the Transaction Value of the goods concerned.

If for the purpose of the said addition there is no real evidence or objective and measurable data, then the transaction value of the imported goods concerned cannot be determined as customs value based on the Transaction Value of the goods concerned.

\section{The amount of insurance costs used in determining the Customs Value}

Based on article 21 paragraph (1) PMK Number 160/PMK.04/2010, it has been explained the amount of insurance costs used in determining Customs Value as quoted below: In the event that insurance costs as referred to in Article 5 paragraph (3) letter g do not include in the transaction value and real evidence or objective and measurable data regarding the amount of insurance costs are not available, the amount of insurance costs used in determining the customs value as referred to in Article 18 is $0.5 \%$ (zero point five percent) of the Cost and Freight value (CFR). 
Based on Article 21 paragraph (3) PMK 160/PMK.04/2010 states: "In the event that the insurance costs as referred to in Article 5 paragraph (3) letter g are closed in the Customs Area based on real evidence or objective and measurable data, then the amount of insurance fee used in determining the customs value as referred to in Article 18 is considered 0 (zero)."

\section{Guarantee from an Insurance Company (Customs Bond) as a Guarantee of Customs Collections and Guarantees Customs Facilities}

Customs is closely related to the payment of state levies. In practice, service users are sometimes unable to pay off the levy immediately. The Directorate General of Customs and Excise (DJBC) provides an opportunity to use guarantees for customs purposes as an option or solution to this.

In the case of an engagement with the Guaranteed, the Collateral can be used to fulfill the obligation to deliver the guarantee required in the customs regulations or to guarantee the payment of state levies on: a) Postponement of payment on imports; b) releasing imported goods for use by submitting guarantees; c) temporary imports; or d) filing an objection (Nurgiyanti \& Fithriya, 2019).

Guarantees from insurance companies that can be accepted are in the form of a Customs Bond. Customs Bonds must be issued by Surety or an insurance company that is included in the list of general insurance companies that can market Customs Bond products based on a Decree of the Minister of Finance.

Collateral in the form of a Customs Bond is a guarantee in the form of a certificate that guarantees payment of state levies in the context of customs activities and/or fulfillment of the obligation to submit guarantees required by customs regulations to the obligee in the event that the company fails to fulfill its payment obligations in accordance with the legislation in the customs sector. . Surety, principal and obligee are guarantor, company, and recipient of guarantee as referred to in the legislation in the field of insurance.

The use of guarantees from insurance companies (customs bonds) as a solution for paying state levies for companies that are unable to pay off the levy immediately and in utilizing customs facilities aimed at boosting national export performance. Among the customs facilities that can be utilized are bonded zone facilities and facilities for Imports for Export Purposes (KITE). Both facilities are intended to provide fiscal and procedural facilities to producer exporters whose use requires guarantees, one of which is a guarantee from an insurance company.

\section{The Successful Utilization of Customs Regulations Related to Import Export Insurance in Supporting the Export Process}

This community service activity was opened by the host and cohost who opened and bridged the event. During the presentation, the resource persons were accompanied by a moderator in guiding the delivery of material and discussions. In each session, a question and answer session was opened for all participants which went smoothly and was guided by a moderator. Participants who come from various professional backgrounds and experiences raise many questions that arise. Although they were unable to respond to all the questions due to time constraints, most of the participants' questions had been answered and received positive responses from the participants as indicated by the results of the evaluation survey.

At the end of the activity, all participants are encouraged to provide feedback in the form of input or suggestions related to the implementation of activities by filling out online questionnaires. Based on the feedback that has been obtained, this activity provides great benefits for participants and motivates participants to improve their understanding both from an academic and practical perspective related to customs regulations on import-export 
insurance. As a form of appreciation to the resource persons, the organizers provided speaker certificates (Figure 4).

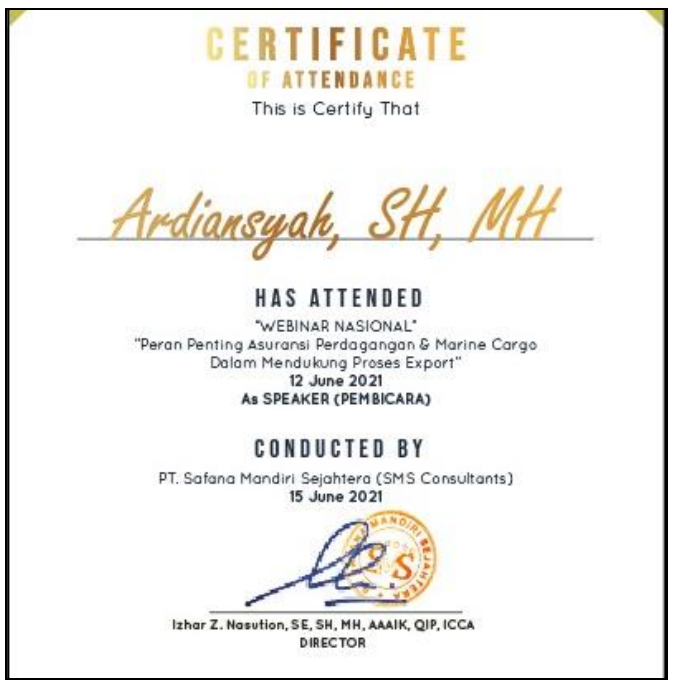

Figure 4. Awards to Speakers in the Form of Speaker Certificates

\section{CONCLUSION}

This community service activity aims to provide education for practitioners and academics in the insurance sector in understanding more deeply the use of customs regulations related to import export insurance in order to strengthen the important role of trade insurance and marine cargo in supporting the export process. There are various customs regulations that can be used by businesses related to insurance, namely: First, the use of domestic insurance will reduce the payment of import duties and taxes for imports because they are not included in the import value. Second, the use of guarantees from insurance companies (customs bonds) as a solution for paying state levies for companies that are unable to pay off these levies immediately and in utilizing customs facilities aimed at boosting national export performance. Among the customs facilities that can be utilized are bonded zone facilities and facilities for Imports for Export Purposes (KITE). Both facilities are intended to provide fiscal and procedural facilities to producer exporters whose use requires guarantees, one of which is a guarantee from an insurance company (customs bond). Based on this activity, participants can take advantage of customs regulations related to importexport insurance which ultimately aims to encourage export activities, especially during this pandemic.

\section{ACKNOWLEDGEMENT}

The author expresses his deepest gratitude to all committee members who contributed and provided support in this community service activity.

\section{REFERENCES}

Afandi, M. M. (2011). Peran dan Tantangan Asean Economic Community (AEC) Dalam Mewujudkan Integrasi Ekonomi Kawasan di Asia Tenggara. SPEKTRUM, 8(1).

Ashar, S. R. (2019). Pemanfaatan Fasilitas Kemudahan Impor Tujuan Ekspor untuk Meningkatkan Ekspor dalam Negeri (Studi pada Kantor Wilayah Direktorat Jenderal Bea Cukai sulawesi Bagian Selatan) (Doctoral dissertation, Universitas Islam Negeri Alauddin Makassar).

Bahagiawati, B., \& Sutrisno, S. (2007). Pemanfaatan tanaman hasil rekayasa genetik: Status, regulasi, dan metode deteksi di Indonesia. Jurnal AgroBiogen, 3(1), 40-48. 
Caraka, R. E., Lee, Y., Kurniawan, R., Herliansyah, R., Kaban, P. A., Nasution, B. I., ... \& Pardamean, B. (2020). Impact of COVID-19 large scale restriction on environment and economy in Indonesia. Global Journal of Environmental Science and Management, 6(Special Issue (Covid-19)), 65-84.

Deyanputri, N. F. (2020). Pengaruh Kebijakan Penurunan Ambang Batas Pembebasan Bea Masuk Nilai Impor Barang Kiriman (De Minimis) terhadap Volume Impor Barang Kiriman Indonesia (PMK No. 199/PMK. 10/2019). Transparansi: Jurnal Ilmiah Ilmu Administrasi, 3(2), 149-159.

Djunaidi, A., Prasetyo, A., \& Putra, R. K. (2019). Efektivitas Pengawasan Kepabeanan Impor Terkait Dengan Kebijakan Asean-China Free Trade Area Di Kantor Pelayanan Utama Bea Dan Cukai Tipe A Tanjung Priok. Jurnal Pajak Vokasi (JUPASI), 1(1), 39-49.

Fatimah, A. M., Friga, S. R., Nataliawati, S., \& Hakimul, B. (2016). Gasifikasi Biomassa: Studi Kasus Proyek di Desa Munduk, Buleleng, Bali. Indonesian Institute for Energy Economics.

Firmansyah, A., \& Arham, A. (2021). Strategi peningkatan ekspor UMKM Indonesia selama pandemi Covid-19. Media Mahardhika, 20(1), 50-68.

Kartika, S. D. (2016). Keamanan Maritim Dari Aspek Regulasi Dan Penegakan Hukum (Maritime Security From The Aspects Of Regulation And Law Enforcement). Negara Hukum: Membangun Hukum untuk Keadilan dan Kesejahteraan, 5(2), 143-167.

Li, L. (2014). The impact on Customs of the implementation of the ASEAN-China FTA. World Customs Journal, 8(1), 87-98.

Nurgiyanti, T., \& Fithriya, D. N. L. (2019, November). Pemanfaatan Literasi Digital Sebagai Upaya Pemerintah Indonesia Dalam Meningkatkan Daya Saing Produk Kosmetik Indonesia Melalui Ecommerce. In Prosiding Seminar Nasional Multidisiplin Ilmu (Vol. 1, No. 2, pp. 101-109).

Rosenow, S., \& O'Shea, B. J. (2010). A handbook on the WTO customs valuation agreement. Cambridge University Press.

Safari, A. T. (2020). Meneropong Dampak Regulasi Tatalaksana Pengawasan Kepabeanan Dan Cukai. Jurnal Perspektif Bea dan Cukai, 4(1).

Sinaga, D. S., \& Rivani, E. (2020). Peluang dan Tantangan Dalam Kebijakan Pemungutan Pajak dan Penetapan Tarif Kepabeanan E-Commerce. Kajian, 23(1), 1-16.

Soebandriyo, S., Santoso, S., \& Saptono, H. (2012). Kelayakan Potensi Daerah Dalam Mendukung Pengembangan Investasi Di Jawa Tengah. Jurnal Litbang Provinsi Jawa Tengah, 10(1), 71-80.

Syaifullah, S., \& Ramdany, R. (2020). Mengukur Tingkat Kepatuhan Kepabeanan Perusahaan Eksport Dan Import Di Indonesia. Jurnal Akuntansi, 9(1), 69-89.

Wolfrum, R., Stoll, P. T., \& Hestermeyer, H. (2009). Agreement On Implementation Of Article VII of the General Agreement on Tariffs And Trade 1994. In WTO-Trade in Goods (pp. 861-1030). Brill Nijhoff.

Zakariya, R. (2020). Optimalisasi Peran PPNS Bea dan Cukai Dalam Penanganan Perkara Kepabeanan Perdagangan Satwa Dilindungi. Jurnal Perspektif Bea dan Cukai, 4(1). 